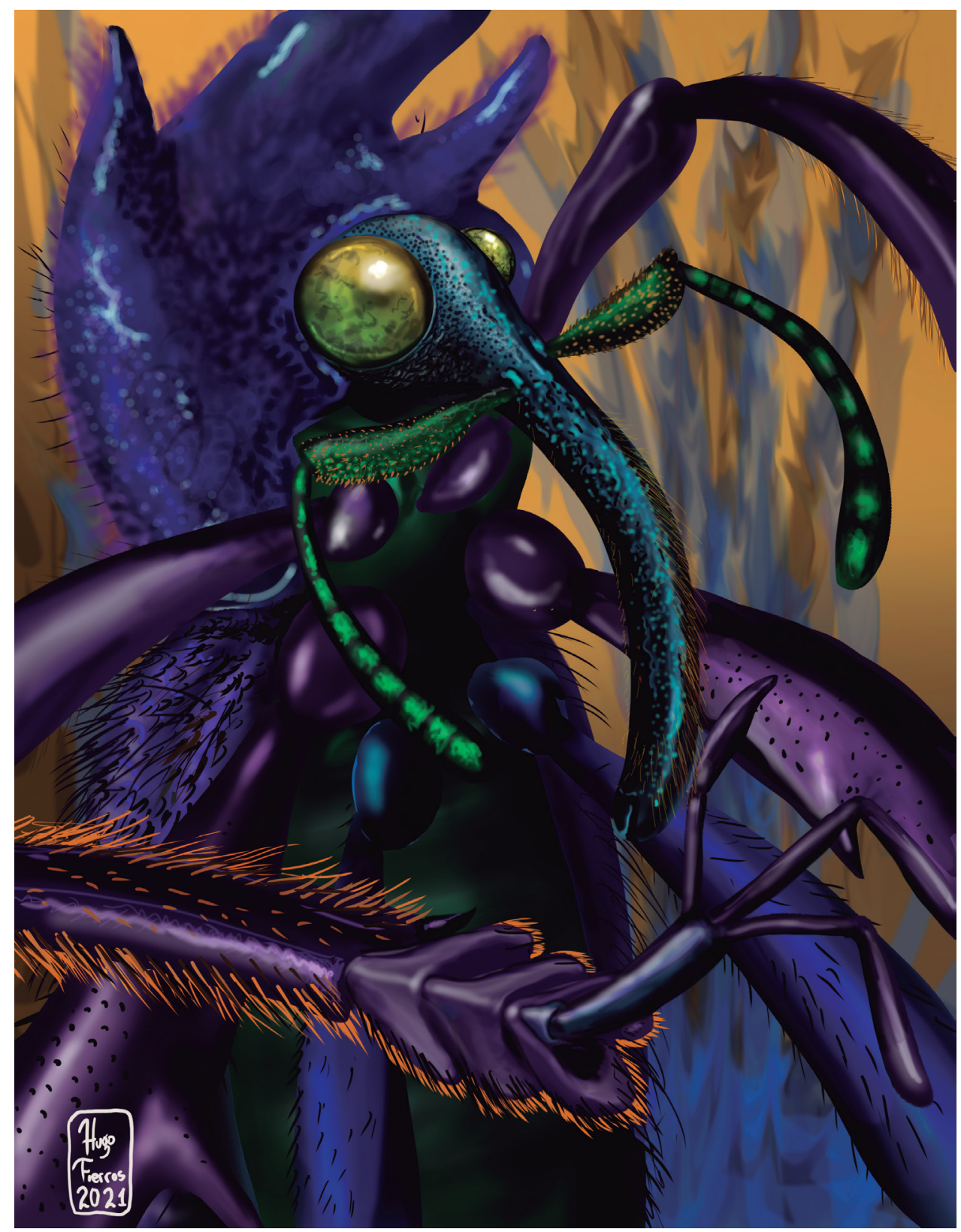

Dugesiana, Año 28, No. 2, (julio-diciembre, segundo semestre de 2021), es una publicación semestral, editada por la Universidad de Guadalajara, a través del Centro de Estudios en Zoología, por el Centro Universitario de Ciencias Biológicas y Agropecuarias. Camino Ramón Padilla Sánchez \# 2100, Nextipac, Zapopan, Jalisco, Tel. 37771150 ext. 33218, http://148.202.248.171/dugesiana/index.php/DUG/index, glenusmx@gmail.com. Editor responsable: José Luis Navarrete-Heredia. Reserva de Derechos al Uso Exclusivo 04-2009-062310115100-203, ISSN: 2007-9133, otorgados por el Instituto Nacional del Derecho de Autor. Responsable de la última actualización de este número: José Luis Navarrete-Heredia, Editor y Ana Laura González-Hernández, Asistente Editorial. Fecha de la última modificación 1 de julio de 2021, con un tiraje de un ejemplar.

Las opiniones expresadas por los autores no necesariamente reflejan la postura del editor de la publicación.

Queda estrictamente prohibida la reproducción total o parcial de los contenidos e imágenes de la publicación sin previa autorización de la Universidad de Guadalajara. 


\title{
Leaf beetles attracted to light in a tropical dry forest of northern Mexico (Coleoptera: Chrysomelidae)
}

\author{
Crisomélidos atraídos a la luz en un bosque seco tropical del norte de México (Coleoptera: Chrysomeli- \\ dae) \\ Geovanni M. Rodríguez-Mirón ${ }^{1,2,3}$, Santiago Zaragoza-Caballero ${ }^{1,4}$, María Magdalena Ordóñez-Re- \\ séndiz ${ }^{2,5}$, Sara López-Pérez ${ }^{1,2,6 *}$ \\ ${ }^{1}$ Departamento de Zoología, Instituto de Biología, Universidad Nacional Autónoma de México. Aparta- \\ do postal 70-153, 04510, Cd. Mx., México; ${ }^{2}$ Colección Coleopterológica, Museo de Zoología, Facultad \\ de Estudios Superiores Zaragoza, Universidad Nacional Autónoma de México, Av. Guelatao 66, Ejército \\ de Oriente, Iztapalapa, CP 09230, Cd. Mx., México. Corresponding author: slopez.p@hotmail.com; \\ ${ }^{3}$ ORCID: https://orcid.org/0000-0003-0751-4672; ${ }^{4}$ ORCID: https://orcid.org/0000-0002-0235-318X; \\ ${ }^{5}$ ORCID: https://orcid.org/0000-0002-2613-9735; ${ }^{6}$ ORCID: https://orcid.org/0000-0002-9925-0186
}

\begin{abstract}
This is the first study of the composition of leaf beetles attracted to light in Mexico. We analyze the richness, temporal abundance and similarity between four localities of tropical dry forest in Sierra de San Javier, Sonora. A total of 3217 individuals belonging to 45 morphospecies, 31 genera and 10 tribes within five subfamilies of Chrysomelidae were collected in light traps in the tropical dry forest of Sierra de San Javier, Sonora. Galerucinae was the subfamily with the greatest number of genera and species. The genera with the highest number of species were Pachybrachis Chevrolat and Alagoasa Bechyné. Eight genera were represented by two species and 21 genera by only one species. Metrioidea rugipennis (Blake) was the species with the highest number of individuals $(80 \%$ of the abundance recorded). According to the taxonomic and species similarity analysis, the sites San Javier and La Barranca had the highest similarity, while the lowest values were recorded at Rancho Las Peñitas and Cañón de Lo de Campa. The low similarity between sites cannot be explained by the geographic distance since it was not a determining factor to explain the low similarity in Sierra de San Javier.

Key words. Light trap, nocturnal chrysomelids, taxonomic similarity
\end{abstract}

\section{RESUMEN}

Este trabajo es el primer estudio sobre la composición de crisomélidos atraídos a la luz en México. Se analizó la riqueza, la abundancia temporal y la similitud entre cuatros localidades de bosque tropical seco en la Sierra de San Javier, Sonora. Se colectaron un total de 3217 individuos pertenecientes a 445 morfoespecies, 31 géneros y 10 tribus dentro de cinco subfamilias de Chrysomelidae en un bosque seco tropical de la Sierra de San Javier, Sonora. Galerucinae fue la subfamilia con el mayor número de géneros y especies. Los géneros con un mayor número de especies fueron Pachybrachis Chevrolat y Alagoasa Bechyné, ocho géneros estuvieron representados por dos especies y 21 por solo una especie. Metrioidea rugipennis (Blake) fue la especie con el mayor número de individuos (80\% de la abundancia registrada). De acuerdo con el análisis de similitud taxonómica y de especies, San Javier y La Barranca tuvieron la mayor similitud, mientras que la menor se encontró en el Rancho Las Peñitas y el Cañón de Lo de Campa. La baja similitud entre los sitios no puede explicarse por la distancia geográfica ya que no fue un factor determinante para explicar la baja similitud en la Sierra de San Javier.

Palabras clave. Crisomélidos nocturnos, similitud taxonómica, trampa de luz

Light affects insect activity and development in several ways. Insects exhibit various manifestations to light; phototaxy is the typical response (Jander 1963). When the insects move towards the light source (attraction), the taxi is positive, as it happens with many nocturnal insects; if the insects move away from the light (repulsion), the taxi is negative. Light intensity and wavelength, time of exposure or direction of light source are some of the factors that affect the response of insects to light (Shimoda and Honda 2013). Insect activity is greatest in the first hours after sunset (O’Donnell 2000).

Among Coleoptera, the families most commonly attracted to light are Bostrichidae, Carabidae, Cerambycidae, Curculionidae, Scarabaeidae, Scolytidae and Tenebrionidae (Morón and Terrón 1988). However, there are records indicating that some species of Chrysomelidae and Coccinell- idae are attracted to light traps (Yang et al. 2003; Lopatin and Nesterova 2006; Abdullah et al. 2008; Kishimoto-Yamada et al. 2008, 2009; Martínez-Hernández et al. 2010; Jiuxuan et al. 2013; Nalepa 2013; Torkey and Dhafer 2015; González-Ramírez et al. 2017; Medeiros et al. 2017; Sharma et al. 2017; Sia et al. 2017; Van 2017; Nowinszky et al. 2017).

Chrysomelidae is one of the most speciose beetle taxa; the family contains more than 32500 species within 11 subfamilies distributed worldwide (Bouchard et al. 2011; Ślipiński et al. 2011). Mexico has 2508 species recorded; however, it is estimated that there are 3532 species (Ordóñez-Reséndiz et al. 2014; Ordóñez-Reséndiz and LópezPérez in press). Comparing this number of species with countries like Brazil (4486 spp.), Mexico has a considerable richness of leaf beetles (Costa 2000; Ordóñez-Reséndiz et 
al. 2014). Ordóñez-Reséndiz and López-Pérez (in press) documented the state distribution of Mexican leaf beetles based on published literature and examination of specimens in some museum collections, most of the species of leaf beetles are recorded from Veracruz (930), Oaxaca (782) and Guerrero (645), Sonora state has 218 species recorded; however, faunistic inventories need to be made in various entities of the country.

Leaf beetles are mainly phytophagous and diurnal insects, they are caught mostly during daylight hours and frequently correspond to the highest proportion of beetle individuals collected (Riley et al. 2002; González-Ramírez et al. 2017). However, some species of the genera Luperodes, Monolepta, Phyllotreta, among others, have been collected in light traps (Yang et al. 2003; Lopatin and Nesterova 2006; Abdullah et al. 2008; Kishimoto-Yamada et al. 2008, 2009; Martínez-Hernández et al. 2010; Torkey and Dhafer 2015; Medeiros et al. 2017).

Most of the studies carried out in Mexico have been carried out during daylight hours and they are biased to certain geographic areas and certain vegetation such as low thorn forests, oak forest or pine-oak forest (Niño-Maldonado et al. 2014a, 2014b, 2016; Furth 2009; Ordóñez-Reséndiz 2016, Sandoval-Becerra et al. 2017; Sanchez-Reyes et al. $2015,2019)$ and tropical dry forest (Ordóñez-Reséndiz and López-Pérez 2009).

One of the reasons why many studies on chrysomelids have focused on the tropical dry forest (TDF) is because it is one of the most diverse vegetation of American tropical ecosystems. TDF present a heterogeneous and widely distributed vegetation type, and their different variants show particular physiological and phenological adaptations in plants and animals (Prieto-Torres et al. 2016). It covers 8\% of the land area in Mexico, distributed in the continental slope of the Mexican Pacific, with Sonora being the northern limit. However, in Mexico, this type of vegetation has been altered by human activities; in 1990 only $27 \%$ of the original TDF remained intact (Trejo and Dirzo 2000), but there are not precise estimates of its deforestation rate.

Little is known about which and how many species of leaf beetles are collected in light traps. Thus, the objective of this work is providing the first insight into the composition of leaf beetles in Mexico collected by light traps, also we analyze the richness, temporal abundance and similarity between four localities of TDF in Sierra de San Javier, Sonora.

\section{MATERIAL AND METHODS}

Study site

The study was conducted in Sierra de San Javier, Sonora, northern Mexico (Fig. 1). This site is considered a priority terrestrial conservation region in Mexico; the vegetation is classified as TDF (Arriaga et al. 2000). According to the Köppen system modified by García (1981), the main climate of the region is semi-warm temperate, with hot summers and rains occurring predominantly in summer and infrequently in winter. The weather is considered very extreme [type (A)Ca( $\left.\mathrm{w}_{0}\right)\left(\mathrm{x}^{\prime}\right)\left(\mathrm{e}^{\prime}\right)$ ], with $14.2{ }^{\circ} \mathrm{C}$ thermal oscillation, $18.7^{\circ} \mathrm{C}$ annual mean temperature, and 638.2 mm annual mean precipitation (Noguera et al. 2009).

\section{Sampling procedures}

The data considered in this study are part of the project "Los Insectos del Bosque Seco (LIMBOS)". The sampling with lights traps was designed to collect longhorn beetles, which have their most richness during the months rainy season (Noguera et al. 2002; 2007; 2009). Samples were taken in November 2003 and February, April, July, August, September and October 2004. The sampling sites were chosen in poorly lit areas along Highway 16 (Hermosillo-Cuauhtémoc) near the village of San Javier.

Site 1: Rancho Las Peñitas, 28 32'21.7'N 109'41'31.5" W, 645-733 m elevation; $29 \mathrm{~km}$ SE of Tecoripa, a road crosses the "Rancho Las Peñitas" property in a southerly direction and extends $6 \mathrm{~km}$ until reaching a small dam. Site 2: San Javier, $28^{\circ} 34^{\prime} 53^{\prime \prime} \mathrm{N}, 109^{\circ} 44^{\prime} 51.5^{\prime \prime} \mathrm{W}, 795$ m elevation; km 120 Hermosillo-Yécora highway, $20 \mathrm{~km}$ of Tecoripa. Site 3: La Barranca, 28 $34^{\prime} 40.1^{\prime \prime} \mathrm{N}, 109^{\circ} 39^{\prime} 54.3^{\prime} \mathrm{W}$, $562 \mathrm{~m}$ elevation; $37 \mathrm{~km}$ SE of Tecoripa and parallel to the highway, in deep canyons where a stream runs seasonally. Site 4: Cañón de Lo de Campa, 28 32' 18.2N, 10944'37.7”" W, 433 m elevation; Rancho El Cajón, Km 124.4 Hermosillo-Yécora highway, $24.4 \mathrm{~km} \mathrm{SE}$ of Tecoripa.

\section{Light trap design}

For light trapping, a combination of two light sources was used: a mercury vapor lamp and a Minnesota-type light trap (see Southwood 1966). The latter had two $20 \mathrm{~W} \mathrm{UV}$ tubes (one unfiltered) over a single $20 \mathrm{~cm}$ diameter collection jar filled with $70 \%$ ethyl alcohol. The light trap and the mercury vapor lamp were placed against a vertical white sheet measuring $1.80 \times 1.50 \mathrm{~m}$. The traps were placed at the same place during each collection session and alternating a day in each one of them. The traps were operated beginning at the twilight for four hours one day each month, from 20:00 to $24: 00 \mathrm{~h}$ during the daylight-saving time during April to October and from 19:00 to 23:00 the rest of the year.

\section{Data analysis}

The richness and abundance values correspond to the number of species and individuals collected in the four sampling sites. The difference in richness and abundance of species was observed for each month to understand the local and temporal distribution pattern of the species. To estimate the richness, three non-parametric estimators were used based on species abundance and/or incidence, Chao 1, ACE and Jacknife 2. This analysis was performed using EstimateS 9.1.

To know the similarity between pairs tramps we used two measures: species similarity and taxonomic similarity. The similarity of species was measured by the Jaccard index (J) (Jaccard 1912). Taxonomic similarity was measured by the method of Bacaro et al. (2007), so that total taxonomic similarity equals the Jaccard similarity coefficient, but also taking into account higher taxa. Taxonomic similarity has advantages over conventional similarity indices which utilize data at the species level only, since it makes 
comparisons between sites or areas by taking into account higher taxonomic levels. For example, in a pair of sites that have exactly the same species similarity, the two sites may have higher taxonomic similarity than another pair if the former has more shared higher taxa, such as genera and families (Calderón-Patrón et al. 2016; García de Jesús et al. 2016). Both indices were calculated with Past 3.0 (Hammer et al. 2001). To calculate the taxonomic similarity, the matrix was configured to represent the higher taxonomic levels and was calculated with the Jaccar index.

Additionally, to discard an influence of the geographic distance on the similarity and know the relationship between the species and taxonomic similarity, we used a Mantel test with the average lineal distance between pairs of traps expressed in kilometers. Mantel correlation were calculated with Past 3.0 (Hammer et al. 2001).

\section{Richness and abundance}

A total of 3217 individuals belonging to 45 species, 31 genera and 10 tribes within five subfamilies of Chrysomelidae were caught in light traps (Fig. 2). The estimates of the richness of leaf beetles attracted to light were higher $(62.14$ to 69.59 species) than the number of species observed; thus, the richness observed represents between 64.72 to $72.41 \%$ of the total estimated (Fig. 3). The subfamily with the greatest number of genera and species was Galerucinae, with three tribes, 19 genera (61\% of the total) and 26 species (59\% of the total). Cryptocephalinae was represented by two tribes, five genera (16\%) and 10 species $(22 \%)$ (Table 1). Alticini was the tribe represented by the greatest number of species (19 spp.), followed by Cryptocephalini with seven, Eumolpini with five, Luperini with four, Galerucini with three. Clytrini was the tribe with the fewest species richness (just two species registered). Bruchini, Cassidini, Megascelidini and Typophorinini were represented by a single species. The genera with the highest number of species were Pachybrachis Chevrolat with four and Alagoasa Bechyné with three. The genera Brachypnoea Gistel, Chaetocnema Stephens, Colaspis Fabricius, Derospidea Blake, Epitrix Foundras, Griburius Haldeman, Metrioidea Fairmaire and Systena Chevrolat were represented by two species each one and twenty-one genera were represented by a single species.

The abundance pattern of leaf beetles attracted to light (Fig. 4) showed the dominance of one species with several codominant species and many others were represented by a few or one individual only. Metrioidea rugipennis (Blake) was the most abundant species, with 2573 specimens, which represented more than $80 \%$ of all individuals sampled. Other codominant species were Walterianella durangoensis (Jacoby), Derospidea brevicollis (LeConte), Derospidea sp., Alagoasa virgata (Harold) and Metrioidea varicornis (LeConte), Trirhabda sp., and Pachybrachis sp.1 (Table 1).

Most of Chrysomelidae species collected in light traps were active mainly from June to October (rainy summer season). The highest numbers of species were recorded during July (24), August (22) and September (11); only one species was collected in April (dry season) (Fig. 5).
Additionally, differences in abundance among moths were also recorded. The highest numbers of individuals were recorded in August (2903) and July (229); in contrast to the months of April with 10 individuals and November with only one (Fig. 5). On the other hand, twenty-six species were caught for one month only, 13 for two months, five for three months, and only $W$. durangoensis was caught from July to October.

\section{Spatial similarity among traps light}

Our results showed a high spatial diversity in San Javier. The species turnover between traps contributes significantly to the richness of the leaf beetles attracted to light. The similarity based on their species structure was always lower than taxonomic similarity. San Javier and La Barranca had the highest similarity (40 and $47 \%$ for species and taxonomic similarity, respectively), while the lowest values were recorded at Rancho Las Peñitas and Cañón de Lo de Campa ( 7 and 17\% for species and taxonomic similarity, respectively) (Table 2). The Mantel test showed that geographic distance was not significant $(\mathrm{P}<0.05)$. There was no decrease in similarity related to geographic distance, neither at the species nor at the taxonomic similarity level.

\section{DISCUSSION}

The leaf beetles caught in this study represents $2 \%$ of the species recorded in Mexico (Ordóñez-Reséndiz and López-Pérez in press). This percentage is low compared with other studies performed in similar vegetation $(13 \%)$ but based on daytime collecting (Ordóñez-Reséndiz and López-Pérez 2009). However, it represents a high percentage of species with a positive phototactic response, which must be studied in the future.

The species of Chrysomelidae collected by light trap in Sierra San Javier were active mainly during the rainy season; there are studies showing that July and August are the months with the greatest number of individuals (Noguera et al. 2009). This high abundance is correlated with the food availability and the seasonality of the TDF, considering that leaf beetles are phytophagous. Moreover, one reason for this response is that during these months the ecological factors in the TDF are favorable for leaf beetles (Sánchez-Reyes et al. 2015).

In the present study, we found a high heterogeneity of chrysomelid species in light traps. The low similarity between the studied sites suggests a particular composition of nocturnal chrysomelids in each area. The relative similarity between San Javier and La Barranca indicates, in this case, that geographic distance has little effect on reducing biological similarity, because these sites are further away from each other than with Rancho Las Peñitas and Cañón de Lo de Campa, so the differences in similarity must obey other aspects of the areas. The floristic composition and the state of conservation of TDF in each site, may be determining different environmental conditions that decreasing similarity (Soininen et al. 2007). However, the geographic distance was not a determining factor in the variation between the species collected. When we incorporated higher taxa into the analysis, more shared elements were included, and the 
composition of communities tends to homogenize. Thus, there is a taxonomic structure common to species attracted to light. Alticini, Galerucini, Luperini, Cryptocephalini, Eumolpini and Megascelidini could be share an evolutionary component. Also, the genera Alagoasa, Pachybrachis, Metrioidea, Griburius, Derospidea, Colaspis, Chaetocnema and Systena. Moreover, these genera have been repeatedly collected in light traps (Andrews and Gilbert 2005; Barney et al. 2013; Riley and Barney 2015; Barney 2018).

Diurnal insects are the least affected by light, but they may fly towards illuminated areas or UV lamps when disturbed (Lewontin 1959; Grewal et al. 2017). There are records of species caught by light traps in studies lasting more than six years, where $32 \%$ of the leaf beetle species were represented by a single specimen only (Kishimoto-Yamada and Itioka 2008; Kishimoto-Yamada et al. 2009). Metrioidea rugipennis represented $80 \%$ of the specimens collected in our study. Moreover, Andrews and Gilbert (2005) recorded $M$. rugipennis as the most abundant species collected by UV light trap in Baja California, Mexico. Some insects have made evolutionary transitions to nocturnality; these changes have been observed between congeneric species, presumably because of lower predation and competition pressures (Somanathan et al. 2008, 2009); it could be the case of this species.

Our study set-up allows us to observe the heterogeneity of light-attracted leaf beetle species and the relationship among them. It is necessary more studies to know if light traps could be a complementary method to collect leaf beetles.

\section{ACKNOWLEDGMENT}

This work is presented in honor of Dr. Juan José Morrone Lupi, a Mexican entomologist dedicated to the study of the family Curculionidae. SZC thank to Felipe A. Noguera, Enrique González Soriano, Verónica Jiménez Gutiérrez, Víctor Hugo Toledo, Lucía del Carmen Salas Arcos and Don Cruz for their help in field work. Field work was financed by Consejo Nacional de Ciencia y Tecnología CONACYT (2002-CO1-02580). We thank Daniel Curoe for edits and comments to the manuscript, and two anonymous reviewers whose comments improved this manuscript.

\section{LITERATURE CITED}

Abdullah, F., S. Kamarulnizam and I. Sina. 2008. Leaf Beetle (Coleoptera: Chrysomelidae) Fauna at Lake Kenyir in Terengganu, Malaysia. The Malaysian Forester, 71(2): 259-264.

Andrews, F.G. and A.J. Gilbert. 2005. A preliminary annotated checklist and evaluation of the diversity of the Chrysomelidae (Coleoptera) of the Baja California peninsula, Mexico. Insecta Mundi, 19(1-2): 89-116.

Arriaga, L., J.M. Espinoza, C. Aguilar, E. Martínez, L. Gómez and E. Loa. 2000. Regiones terrestres prioritarias de México. Comisión Nacional para el Conocimiento y uso de la Biodiversidad, México.

Bacaro, G., C. Ricotta and S. Mazzoleni. 2007. Measuring beta-diversity from taxonomic similarity. Journal of Vegetation Science, 18(6): 793-798. https://doi. org/10.1111/j.1654-1103.2007.tb02595.x
Barney, R.J. 2018. Definition and revision of the atomarius species-group of north American Pachybrachis Chevrolat (Coleoptera: Chrysomelidae: Cryptocephalinae), including descriptions of nine new species. The Coleopterists Bulletin, 72(1): 9-74. https://doi. org/10.1649/0010-065X-72.1.9

Barney, R.J., L. LeSage and K. Savard. 2013. Pachybrachis (Coleoptera, Chrysomelidae, Cryptocephalinae) of Eastern Canada. ZooKeys, (332): 95-176. https://doi. org/10.3897/zookeys.332.4753

Bouchard, P., Y. Bousquet, A.E. Davies, M.A. Alonso-Zarazaga, J.F. Lawrence, C.H.C. Lyal, A.F. Newton, C.A.M. Reid, M. Schmitt, S.A. Ślipiński and A.B.T. Smith. 2011. Family-group names in Coleoptera (Insecta). ZooKeys, (88): 1-972. https://doi.org/10.3897/ zookeys. 88.807

Calderón-Patrón, J.M., I. Goyenechea, R. Ortiz-Pulido, J. Castillo-Cerón, N. Manriquez, A. Ramírez-Bautista and C.E. Moreno. 2016. Beta diversity in a highly heterogeneous area: disentangling species and taxonomic dissimilarity for terrestrial vertebrates. PloS one, 11(8): e0160438. https://doi.org/10.1371/journal. pone. 0160438

Costa, C. 2000. Estado del conocimiento de los Coleoptera Neotropicales. (pp. 99-114). In Martín-Piera, F., J. J. Morrone and A. Melic (Eds.). Hacia un Proyecto CYTED para el Inventario y Estimación de la Diversidad Entomológica en Iberoamérica. PrIBes 2000, m3m-Monografías Tercer Milenio, Vol. I, Sociedad Entomológica Aragonesa (SEA), Zaragoza, España.

Furth, D.G. 2009. Flea beetle diversity of the Sierra Tarahumara, Copper Canyon, Mexico (Chrysomelidae: Alticinae). (pp. 131-151). In: Jolivet, P., J. Santiago-Blay, M. Schmitt (Eds.). Research on Chrysomelidae, Volume 2. Koninklijke Brill, Leiden. https://doi.org/10.1163/ ej.9789004169470.1-299.45

García de Jesús, S., C.E. Moreno, M.A. Morón, I. Castellanos and N.P. Pavón. 2016. Integrando la estructura taxonómica en el análisis de la diversidad alfa y beta de los escarabajos Melolonthidae en la Faja Volcánica Transmexicana. Revista Mexicana de Biodiversidad, 87(3): 1033-1044. https://doi.org/10.1016/j.rmb.2016.06.003

García, E. 1981. Modificaciones al sistema de clasificación climática de Köppen. Instituto de Geografía, Universidad Nacional Autónoma de México, México, CDMX.

González-Ramírez, M., S, Zaragoza-Caballero and C.X. Pérez-Hernández. 2017. Análisis de la diversidad de Coleoptera en el bosque tropical caducifolio en Acahuizotla, Guerrero, México. Revista Mexicana de Biodiversidad, 88(2): 381-388.

Grewal, P.K., M.I. Ludlam, K.A. Sandquist, S.J. Selje, K.A. Wilcox and K.K. Lam. 2017. Phototactic responses of Drosophila melanogaster to UVA, UVB, white light, and dark environments. Science Undergraduate Research Journal, (3): 14-22.

Hammer, O., D.A. Harper and P.D. Ryan. 2001. PAST: Paleontological statistics software package for education and data analysis. Palaeontologia Electronica, 4(1): $1-9$. 
Jaccard, P. 1912. The distribution of the flora of the alpine zone. New phytologist, 11(2): 37-50. https://doi. org/10.1111/j.1469-8137.1912.tb05611.x

Jander, R. 1963. Insect orientation. Annual Review of Entomology, 8: 95-114.

Kato, M., T. Inoue, A.A. Hamid, T. Nagamitsu, M.B. Merdek, A.R. Nona, T. Itino, S. Yamane and T. Yumoto. 1995. Seasonality and vertical structure of light-attracted insect communities in a dipterocarp forest in Sarawak. Researches on Population Ecology, 37(59): 59-79. https://doi.org/10.1007/BF02515762

Kishimoto-Yamada and K., T. Itioka. 2008. Consequences of a severe drought associated with El Niño Southern Oscillation on a light-attracted leaf-beetle (Coleoptera, Chrysomelidae) assemblage in Borneo. Journal of Tropical Ecology, 24(2): 229-233. https://doi.org/10.1017/ S0266467408004811

Kishimoto-Yamada, K., T. Itioka, S. Sakai, K. Momose, T. Nagamitsu, H. Kaliang, P. Meleng, L. Chong, A.A. Hamid, S. Yamane, M. Kato, C.A.M. Reid, T. Nakashizuka and T. Inoue. 2009. Population fluctuations of light-attracted chrysomelid beetles in relation to supra-annual environmental changes in a Bornean rainforest. Bulletin of entomological research, 99(3): 217-227. https://doi. org/10.1017/S000748530800624X

Lewontin, R. 1959. On the anomalous response of Drosophila pseudoobscura to light. The American Naturalist, 93(872):321-328. https://doi.org/10.1086/282088

Lopatin, I.K. and O.L. Nesterova. 2006. A new species of Acolastus from United Arab Emirates (Coleoptera: Chrysomelidae: Cryptocephalinae). Zoosystematica Rossica, 15(2): 308-308.

Martínez-Hernández, N.J., S. García-Atencia, M.J. Gutiérrez-Cerpa, S. Sanjuán-Murillo and C. Contreras-Mejía. 2010. Composición y estructura de la fauna de escarabajos (Insecta: Coleoptera) atraídos por trampas de luz en La Reserva Ecológica de Luriza, Atlántico, Colombia. Boletín de la Sociedad Entomológica Aragonesa, (47): 373-381.

Medeiros, B.A.S.D., A. Barghini and S.A. Vanin. 2017. Streetlights attract a broad array of beetle species. Revista Brasileira de Entomologia, 61(1): 74-79. https:// doi.org/10.1016/j.rbe.2016.11.004

Nalepa, C.A. 2013. Coccinellidae captured in blacklight traps: Seasonal and diel pattern of the dominant species Harmonia axyridis (Coleoptera: Coccinellidae). European Journal of Entomology, 110(4): 593-597. https:// doi.org/10.14411/eje.2013.080

Niño-Maldonado, S., J.R. Romero-Nápoles, U.J. Sánchez-Reyes, R. Jones and E.I. De León-González. 2014a. Inventario preliminar de Chrysomelidae (Coleoptera) de Tamaulipas, México. (pp. 121-132). In: Correa-Sandoval, A., J.V. Horta-Vega, J. García-Jiménez and L. Barrientos-Lozano (Eds.). Biodiversidad Tamaulipeca, vol. 2 (2) Tecnológico Nacional de México, Instituto Tecnológico de Ciudad Victoria, Tamaulipas, México.

Niño-Maldonado, S., U.J. Sánchez-Reyes, E. Meléndez-Jaramillo, V.C. Gómez-Moreno and J.L. Navarrete-Here- dia. 2014b. Coleópteros Chrysomelidae. In: S. Guerrero, J.L. Navarrete-Heredia and S.H. Contreras-Rodríguez (Eds.). Biodiversidad del Estero El Salado. Jalisco. Universidad de Guadalajara, México.

Niño-Maldonado, S., R.W. Jones, J.A. Obregón, U.J. Sánchez-Reyes and J. Luna. 2016. Chrysomelidae (Coleoptera) del estado de Querétaro. In: Robert, W.J. and V. Serrano Cárdenas (Eds.). Historia Natural de Querétaro. Editorial Universitaria, Colección Academia, Serie Nodos, Querétaro, México.

Noguera, F.A., J.A. Chemsak, S. Zaragoza-Caballero, A. Rodríguez-Palafox, E. Ramírez-García, E. González-Soriano, and R. Ayala. 2007. A faunal study of Cerambycidae (Coleoptera) from one region with tropical dry forest in Mexico: San Buenaventura, Jalisco. The Pan-Pacific Entomologist, 83(4): 296-314.

Noguera, F.A., M.A. Ortega-Huerta, S. Zaragoza-Caballero, E. González-Soriano and E. Ramírez-García. 2009. A faunal study of Cerambycidae (Coleoptera) from one región with tropical dry forest in Mexico: Sierra de San Javier, Sonora. The Pan-Pacific Entomologist, 85(2): 70-90.

Noguera, F.A. S. Zaragoza-Caballero, J.A. Chemsak, A. Rodríguez-Palafox, E. Ramírez-García, E. González-Soriano, and R. Ayala. 2002. Diversity of the family Cerambycidae (Coleoptera) of the tropical dry forest of Mexico, I. Sierra de Huautla, Morelos. Annals of the Entomological Society of America, 95(5): 617-627.

Nowinszky, L., J. Puskás, and M. Kiss. 2017. Light trapping of Coleoptera, Lepidoptera and Heteroptera species in relation to the altitude of the tropopause. Global Journal of Research and Review, 4(2): 1-4. https://doi. org/10.21767/2393-8854.100020

O’Donnell, C. F. J. 2000. Influence of season, habitat, temperature, and invertebrate availability on nocturnal activity of the New Zealand long-tailed bat (Chalinolobus tuberculatus). New Zealand Journal of Zoology, 27(3): 207-221. https://doi/10.1080/03014223.2000.9518228

Ordóñez-Reséndiz, M.M. 2016. Biodiversidad de coleópteros y arañas de las Sierras de Taxco-Huautla. Universidad Nacional Autónoma de México. Facultad de Estudios Superiores Zaragoza. Informe final SNIB-CONABIO, Proyecto No. JF105. México, D. F.

Ordóñez-Reséndiz, M.M., S. López Pérez. 2009. Crisomélidos (Coleoptera: Chrysomelidae) de las Sierras de Taxco-Huautla, México. Entomología Mexicana, (8): 946-951.

Ordóñez-Reséndiz, M.M. and S. López-Pérez. In press. Mexican leaf beetles (Coleoptera: Megalopodidae, Orsodacnidae, and Chrysomelidae): New records and checklist. Revista Mexicana de Biodiversidad.

Ordóñez-Reséndiz, M.M., S. López-Pérez and G.M. Rodríguez-Mirón. 2014. c. Revista Mexicana de Biodiversidad, 85(S1): 271-278. https://doi.org/10.7550/ rmb.31424

Prieto-Torres, D.A., A.G. Navarro-Sigüenza, D. Santiago-Alarcon, and O.R. Rojas-Soto. 2016. Response of the endangered tropical dry forests to climate change and the role of Mexican Protected Areas for their con- 
servation. Global change biology, 22(1), 364-379.

Riley, E.G. and R.J. Barney. 2015. Definition and revision of the viduatus species-group of North American Pachybrachis Chevrolat (Coleoptera: Chrysomelidae: Cryptocephalinae). The Coleopterists Bulletin, 69(1): 25-59. https://doi.org/10.1649/0010-065X-69.1.25

Riley, E.G., S.M. Clark, R.W. Flowers, and A.J. Gilbert. 2002. Chrysomelidae Latreille 1802. (pp. 617-691). In: Arnett R.H., M.C. Thomas, P.E. Skelley, and J.H. Frank (Eds.) Volume 2, American Beetles, Polyphaga: Scarabaeoidea through Curculionoidea. CRC Press LLC, Boca Ratón.

Sánchez-Reyes, U.J., S. Niño-Maldonado, E. Meléndez-Jaramillo, V.D.C. Gómez-Moreno and J.E. Banda-Hernández. 2015. Riqueza de Chrysomelidae (Coleoptera) en el cerro El Diente, San Carlos, Tamaulipas, México. Acta Zoológica Mexicana (nueva serie), 31(1): 10-22. https://doi.org/10.21829/azm.2015.311499

Sandoval-Becerra, F.M., S. Niño-Maldonado, U.J. Sánchez-Reyes, J.V. Horta-Vega, C.S. Venegas-Barrera and I. Martínez-Sánchez. 2017. Respuesta de la comunidad de Chrysomelidae (Coleoptera) a la variación microclimática en un fragmento de bosque de encino del noreste de México. Entomología Mexicana, (4): 420-426.

Sharma, A.K., R. Mandloir, and R. Pachori. 2017. Study on biodiversity of phototactic harmful insect fauna collected in light trap in chickpea (Cicer arietinum Linn.) ecosystem. International Journal of Agriculture Sciences, 9(12): 4037-4040.

Shimoda, M. and K. Honda. 2013. Insect reactions to light and its applications to pest management. Applied Entomology and Zoology, (48): 413-421. https://doi/10.1007/ s13355-013-0219-x

Sia, T.J., N.A.A. Rahman, N.Y. Foo, S. Yaakop, and Z. Akbar. 2017. Insect diversity and abundance during the crepuscular and nocturnal temporal periods in The Kota Gelanggi Limestone Complex, Pahang, Malaysia. Serangga, 21(2): 97-113.

Recibido: 30 abril 2021

Aceptado: 4 junio 2021
Ślipiński, S.A., R.A.B. Leschen, and J.F. Lawrence. 2011. Order Coleoptera Linnaeus, 1758. Animal biodiversity: An outline of higher-level classification and survey of taxonomic richness. Zootaxa, 3148(237): 203-208.

Soininen, J., R. McDonald, and H. Hillebrand. 2007. The distance decay of similarity in ecological communities. Ecography, 30(1): 3-12. https://doi.org/10.1111/j.09067590.2007.04817.x

Somanathan, H., R.M. Borges, E.J. Warrant, and A. Kelber. 2008. Visual ecology of Indian carpenter bees. I. Light intensity and flight activity. Journal of Comparative Physiology A, 194(1):97-107. https://doi.org/10.1007/ s00359-007-0291-1

Somanathan, H., A. Kelber, R.M. Borges, R. Wallén, and E.J. Warrant. 2009. Visual ecology of Indian carpenter bees II: adaptations of eyes and ocelli to nocturnal and diurnal lifestyles. Journal of Comparative Physiology A, 195(6): 571-583. https://doi.org/10.1007/s00359009-0432-9

Southwood, T.R.E. 1966. Ecological methods with particular reference to the study of insect populations. Methuen, London.

Trejo, I. and R. Dirzo. 2000. Deforestation of seasonally dry tropical forest: a national and local analysis in Mexico. Biological conservation, 94(2): 133-142.

Torkey, A.M. and H.M. Dhafer. 2015. Amphimela raydahensis sp. nov. from the Kingdom of Saudi Arabia (Coleoptera: Chrysomelidae: Galerucinae: Alticini). Zootaxa, 4028(3): 430-440. https://doi.org/10.11646/ zootaxa.4028.3.8

Van, P.S. 2017. Nineteen years of recording ladybirds attracted to light (Coleoptera: Coccinellidae). Entomologische Berichten. 77(3): 127-139.

Yang, E.C., D.W. Lee, and W.Y. Wu. 2003. Action spectra of phototactic responses of the flea beetle, Phyllotreta striolata. Physiological Entomology, 28(4): 362-368. https://doi.org/10.1111/j.1365-3032.2003.00351.x 


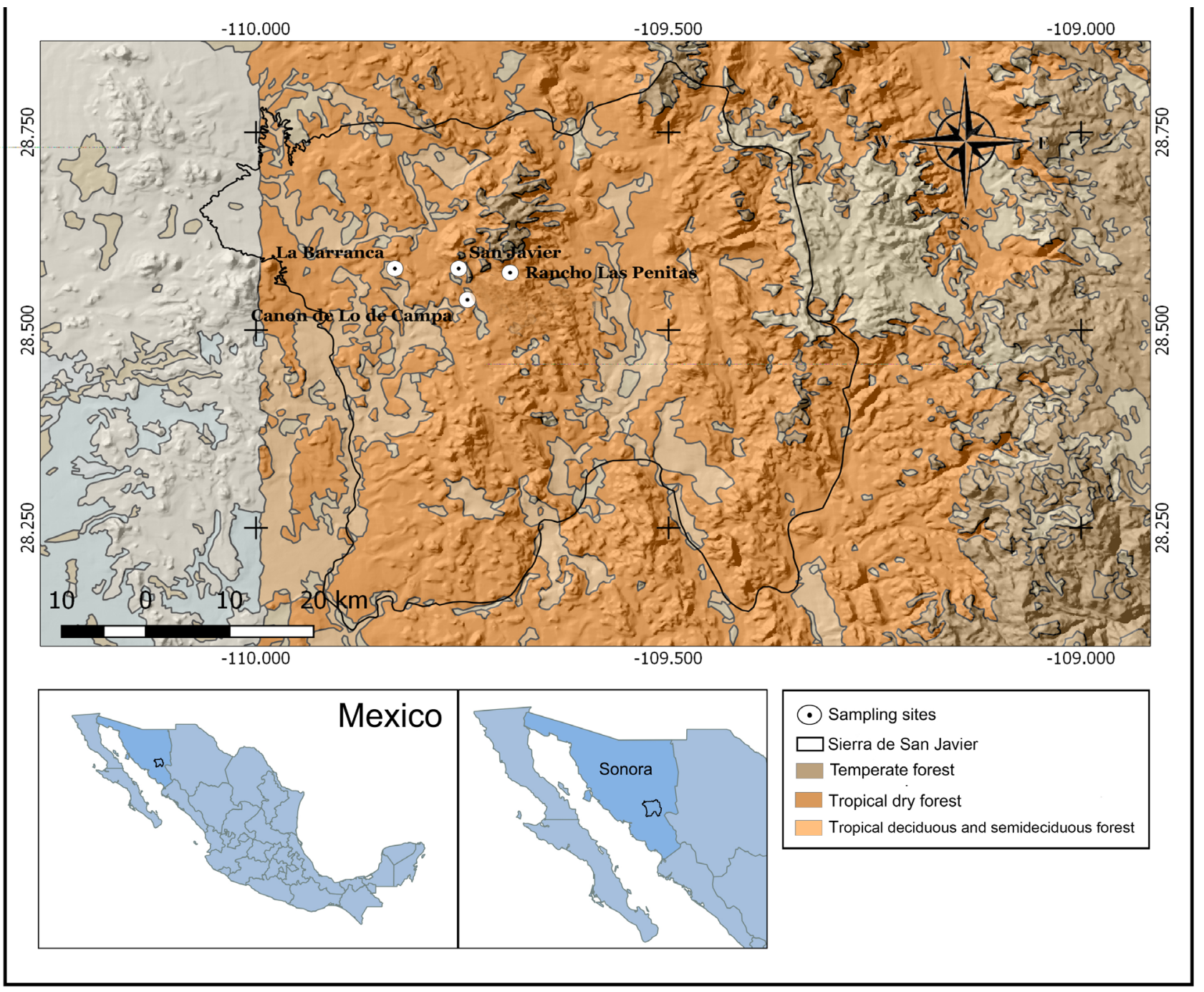

Figure 1. The sampling sites in Sierra San Javier, Sonora. 

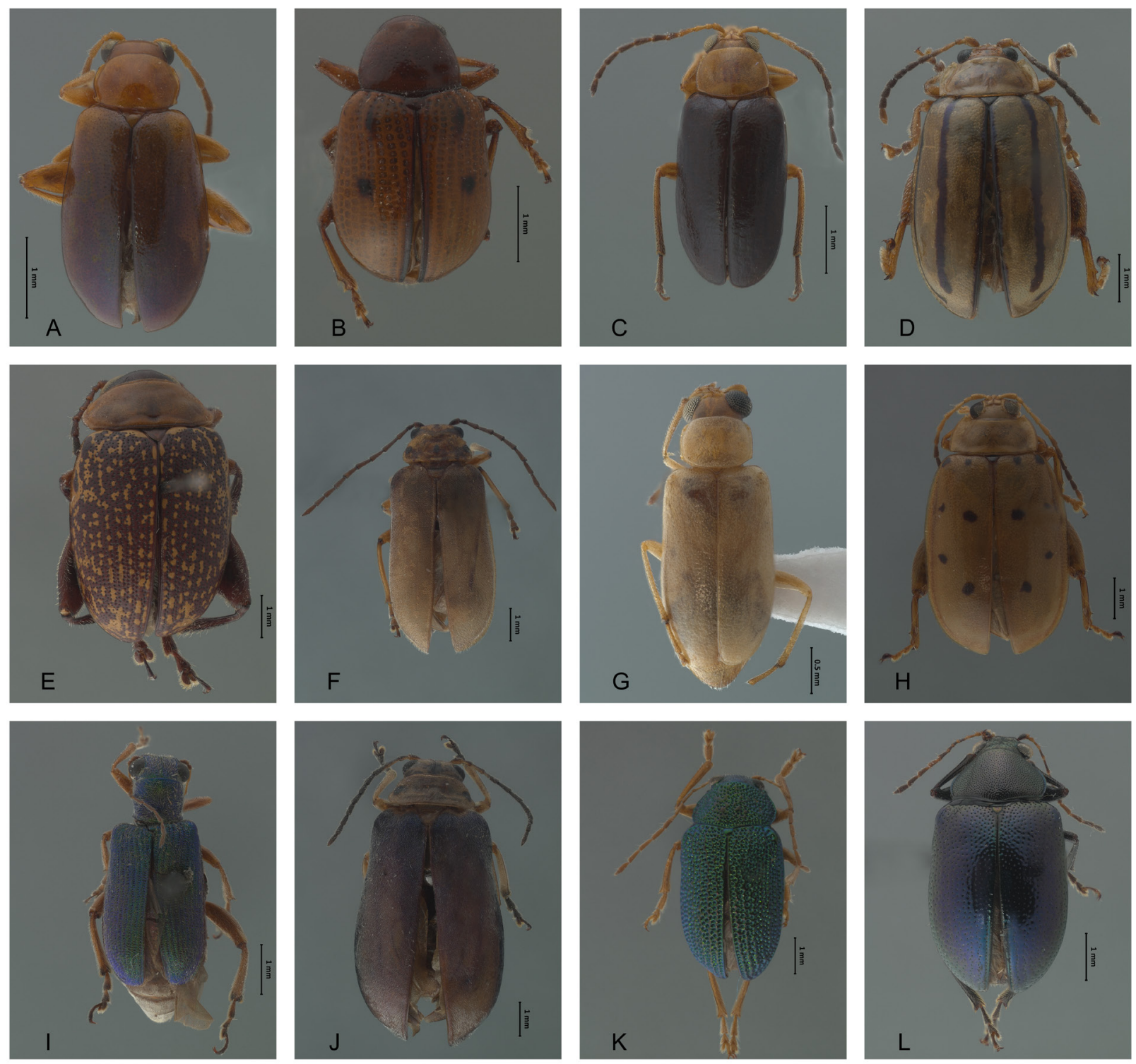

Figure 2. Example of leaf beetle biodiversity from Sierra San Javier, Sonora. A) Lupraea sp.; B) Metachroma sp. 1; C) Metrioidea rugipennis (Blake); D) Alagoasa tenuilineata (Horn); E) Blepharida sp. 1; F) Trirhabda sp. 1; G) Metrioidea varicornis (LeConte); H) Walterianella durangoensis (Jacoby); I) Megascelis sp.; J) Derospidea sp.; K) Colaspis sp. 1; L) Brachypnoea sp. 2. 


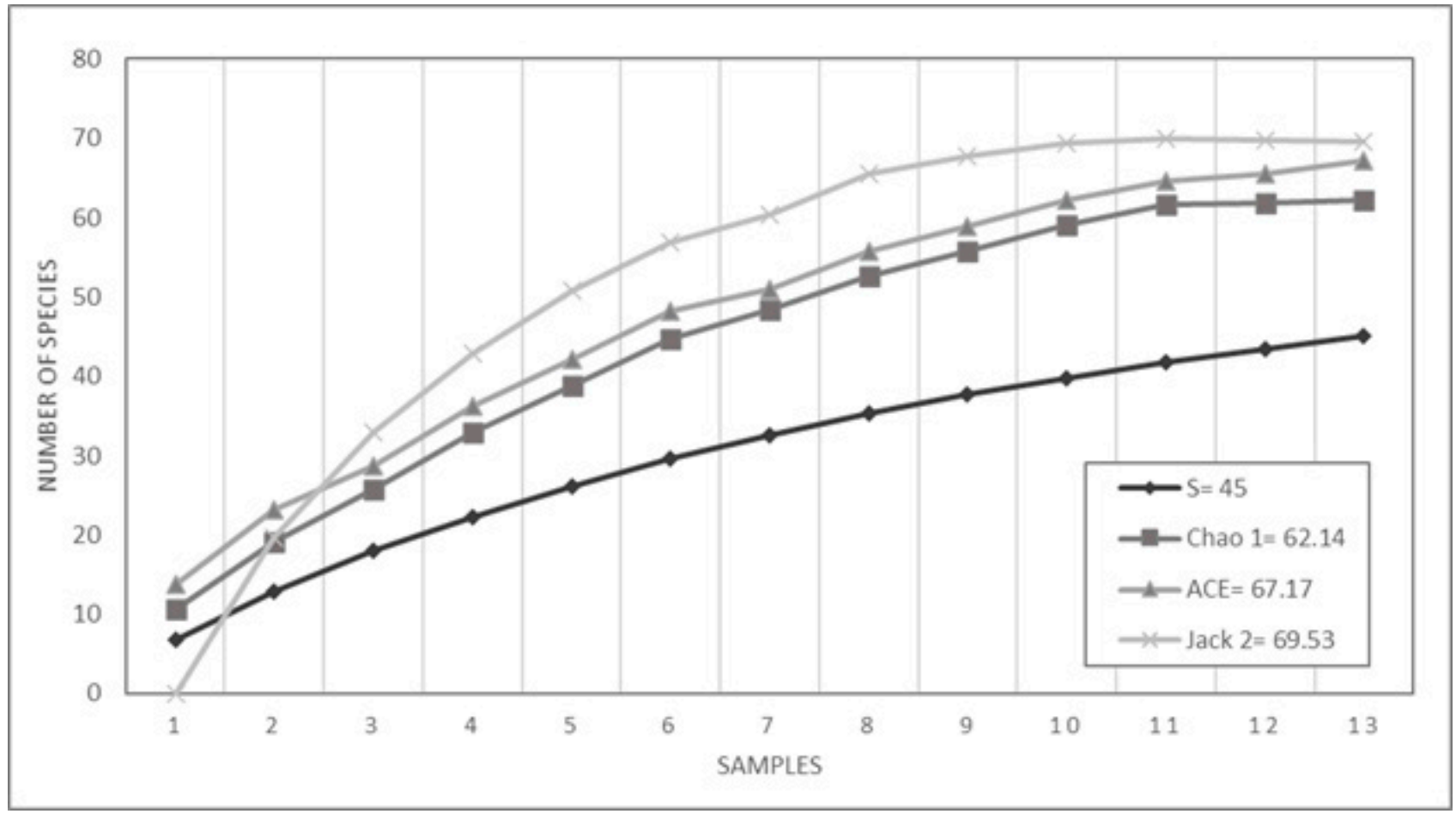

Figure 3. Richness observed and estimated of Chrysomelidae in Sierra de San Javier, Sonora.

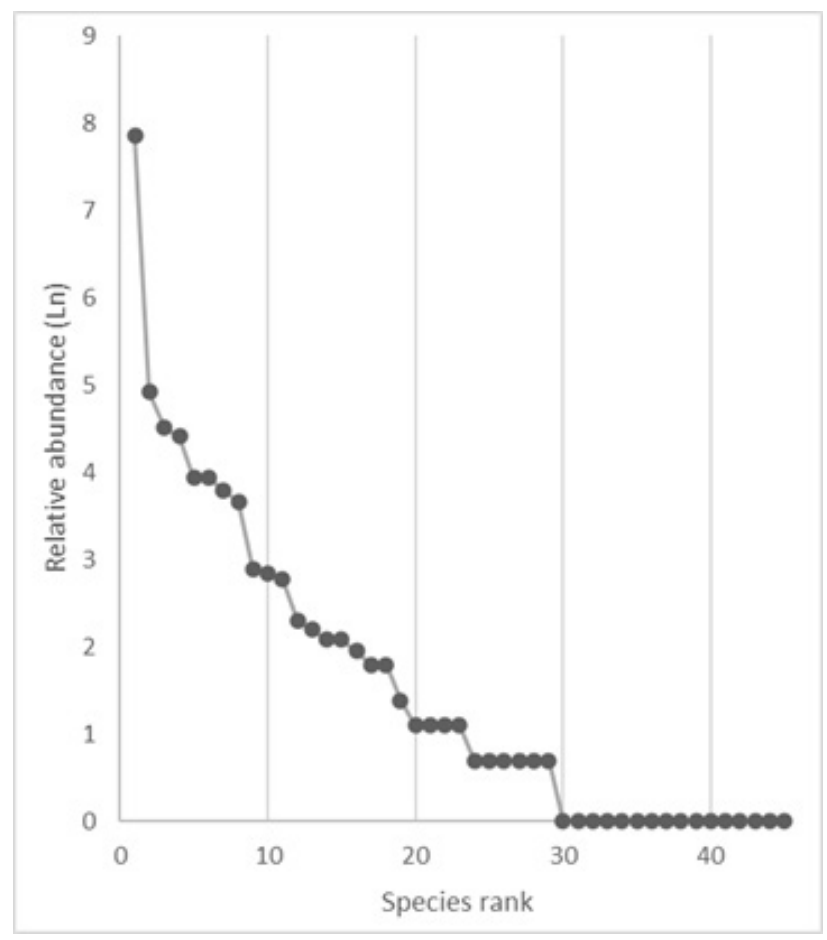

Figure 4. Rank-abundance pattern of the Chrysomelidae species recorded in Sierra de San Javier, Sonora. 


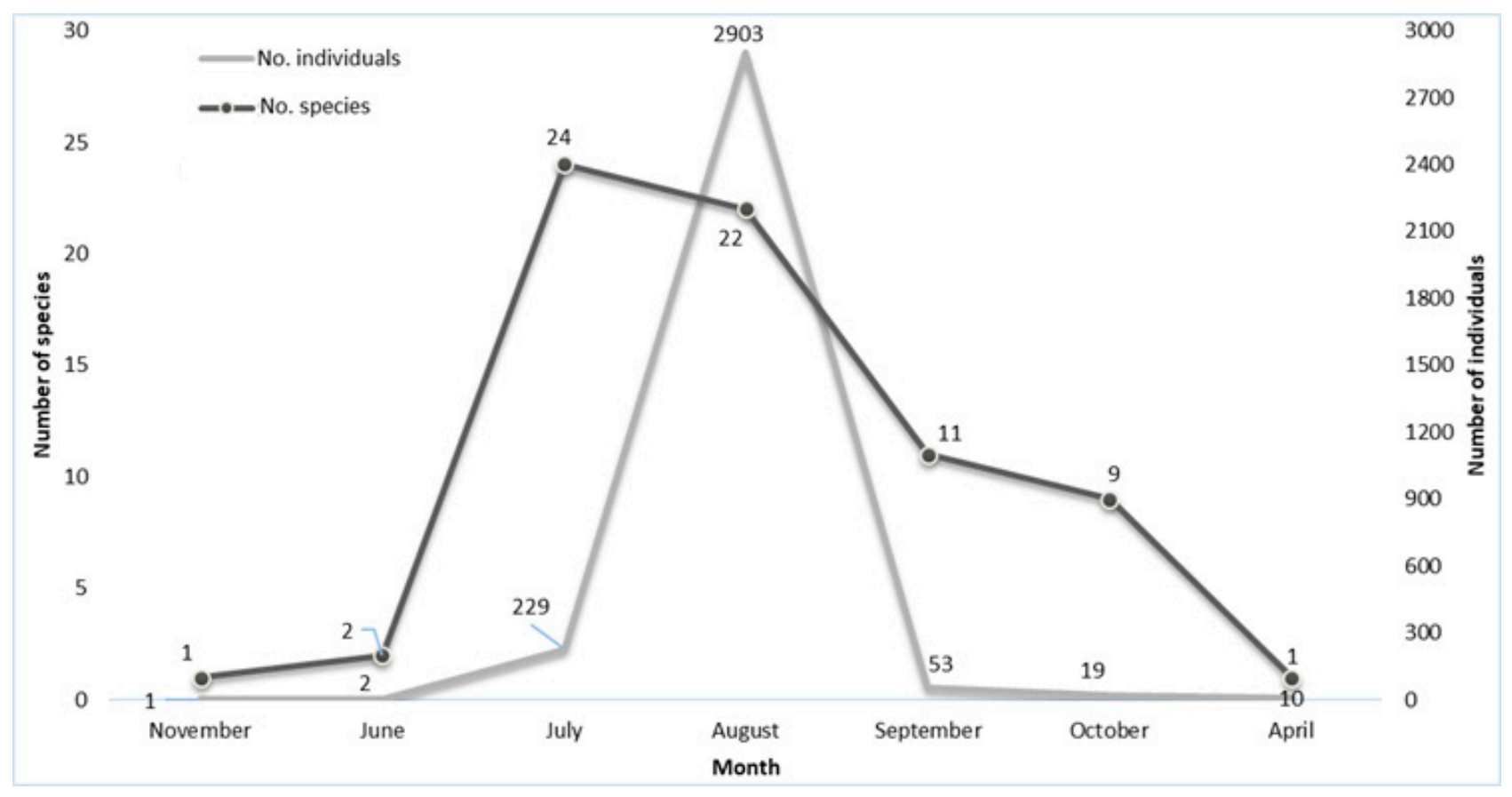

Figure 5. Temporal pattern of species richness and abundance of Chrysomelidae recorded in Sierra de San Javier, Sonora.

Table 1. Checklist of leaf beetles attracted to light in San Javier, Sonora. The number of individuals caught per species is indicated at each site.

\begin{tabular}{|c|c|c|c|c|}
\hline & La Barranca & $\begin{array}{l}\text { Cañón de Lo } \\
\text { de Campa }\end{array}$ & $\begin{array}{l}\text { Rancho Las Pe- } \\
\text { ñitas }\end{array}$ & San Javier \\
\hline \multicolumn{5}{|l|}{ Bruchinae } \\
\hline \multicolumn{5}{|l|}{ Bruchini } \\
\hline Acanthoscelides sp. & & 1 & & \\
\hline \multicolumn{5}{|l|}{ Cassidinae } \\
\hline \multicolumn{5}{|l|}{ Cassidini } \\
\hline Charidotella emarginata (Boheman) & & 1 & & \\
\hline \multicolumn{5}{|l|}{ Chryptocephalinae } \\
\hline \multicolumn{5}{|l|}{ Clytrini } \\
\hline Anamoea sp. & & & 1 & \\
\hline Coscinoptera sp. 1 & 1 & & & \\
\hline Coscinoptera sp. 2 & & & 1 & \\
\hline \multicolumn{5}{|l|}{ Cryptocephalini } \\
\hline Cryptocephalus sp. & 3 & & & \\
\hline Griburius sp. 1 & & 1 & & \\
\hline Griburius sp. 2 & & 1 & & \\
\hline Pachybrachis sp. 1 & 3 & & 36 & \\
\hline Pachybrachis sp. 2 & 2 & & & \\
\hline Pachybrachis sp. 3 & 1 & & & \\
\hline Pachybrachis sp. 4 & 1 & & 2 & \\
\hline
\end{tabular}




\section{Eumolpinae}

\section{Eumolpini}

Brachypnoea sp. 1

Brachypnoea sp. 2

Colaspis sp. 1

Colaspis sp. 2

Euphytus sp.

Megascelidini

Megascelis sp.

Typophorini

Metachroma sp.

\section{Galerucinae}

\section{Alticini}

Alagoasa sp.

Alagoasa tenuilineata (Horn)

Alagoasa virgata

(Harold)

Blepharida sp.

Chaetocnema sp. 1

Chaetocnema sp. 2

Disonycha glabrata (Fabricius)

Dysphenges rileyi

(Gilbert and Andrews)

Epitrix sp. 1

Epitrix sp. 2

Glyptina sp.

Hemiphrynus sp.

Longitarsus sp.

Lupraea sp.

Phylotreta sp.

Syphrea sp.

Systena sp. 1

Systena sp. 2

Walterianella durangoensis (Jacoby)

\section{Galerucini}

Derospidea brevicollis (LeConte)

Derospidea sp.

Trirhabda sp.

\section{Luperini}

Acalymma vittatum (Fabricius)

Diabrotica balteata

LeConte

Metrioidea rugipennis (Blake)

Metrioidea varicornis(LeConte)

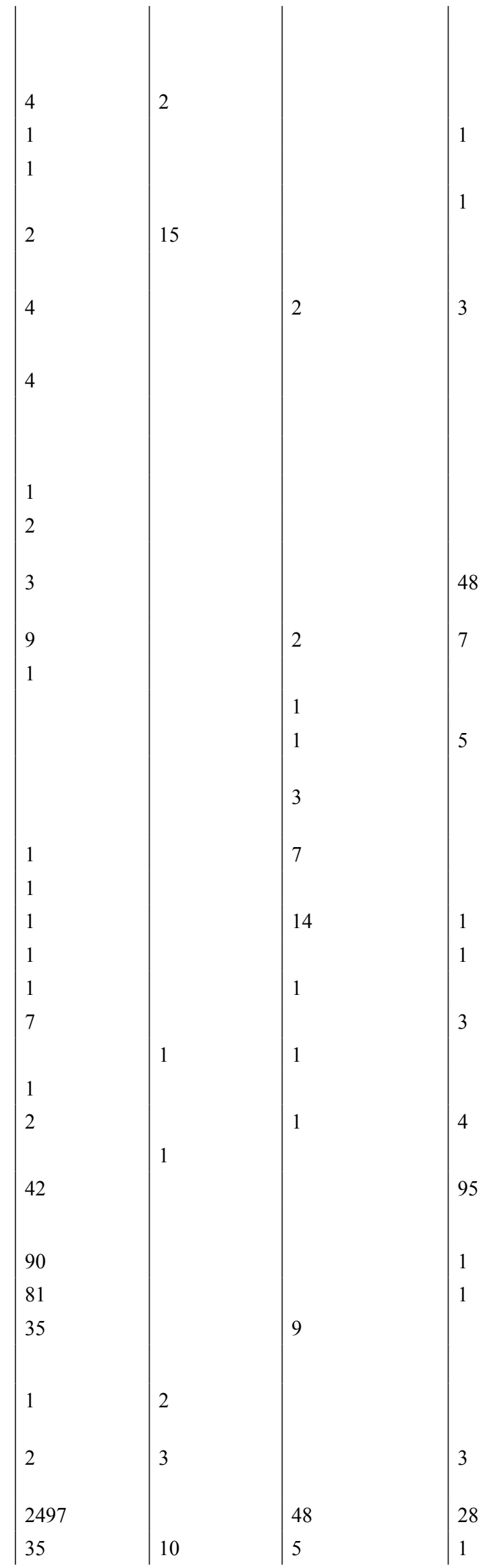


Geovanni M. Rodríguez-Mirón et al.

Table 2. Jaccard similarity between light traps. Upper diagonal $=$ Species similarity. Lower diagonal $=$ Taxonomic similarity.

\begin{tabular}{|l|l|l|l|l|}
\hline & $\begin{array}{l}\text { La Barran- } \\
\text { ca }\end{array}$ & Rancho Las Peñitas & Cañón de Lo de Campa & San Javier \\
\hline La Barranca & & 0.12821 & 0.28205 & 0.4 \\
\hline Rancho Las Peñitas & 0.21951 & & 0.076923 & 0.08 \\
\hline Cañón de Lo de Campa & 0.37975 & 0.17742 & & 0.26923 \\
\hline San Javier & 0.47887 & 0.18966 & 0.32203 & \\
\hline
\end{tabular}

